\title{
Vulvar Sebaceous Carcinoma
}

National Cancer Institute

\section{Source}

National Cancer Institute. Vulvar Sebaceous Carcinoma. NCl Thesaurus. Code C40309.

A carcinoma that arises from the vulva. It is characterized by the presence of malignant basaloid glandular epithelial cells that resemble sebaceous epithelium and are arranged in cords and nests. 